University of Nebraska - Lincoln

DigitalCommons@University of Nebraska - Lincoln

Biological Systems Engineering: Papers and

Publications

Biological Systems Engineering

2008

\title{
Performance Evaluation of Aluminum Test Cell Designed for Determining the Heat Resistance of Bacterial Spores in Foods
}

\author{
H.-J. Chung \\ Washington State University \\ Sohan Birla \\ University of Nebraska-Lincoln, sbirla2@unl.edu \\ Juming Tang \\ Washington State University, jtang@mail.wsu.edu
}

Follow this and additional works at: https://digitalcommons.unl.edu/biosysengfacpub

Part of the Biological Engineering Commons

Chung, H.-J.; Birla, Sohan; and Tang, Juming, "Performance Evaluation of Aluminum Test Cell Designed for Determining the Heat Resistance of Bacterial Spores in Foods" (2008). Biological Systems Engineering: Papers and Publications. 211.

https://digitalcommons.unl.edu/biosysengfacpub/211

This Article is brought to you for free and open access by the Biological Systems Engineering at DigitalCommons@University of Nebraska - Lincoln. It has been accepted for inclusion in Biological Systems Engineering: Papers and Publications by an authorized administrator of DigitalCommons@University of Nebraska Lincoln. 


\title{
Performance Evaluation of Aluminum Test Cell Designed for Determining the Heat Resistance of Bacterial Spores in Foods
}

\author{
H.-J. Chung, S. L. Birla, J. Tang \\ Department of Biological Systems Engineering, Washington State University, \\ 213 LJ Smith Hall, Pullman WA 99164-6120 USA \\ Corresponding author — J. Tang, tel 509-335-2140, fax 509-335-2722. email jtang@mail.wsu.edu
}

\begin{abstract}
Thermal inactivation kinetic studies are necessary to determine heat resistances of spores in the development of new thermal processes for low-acid shelf-stable products. Most currently available sample holders used in the kinetic studies take long time to reach the target sample temperature, hence fail to provide isothermal condition. In this research, novel aluminum test cells were developed to facilitate easy loading and unloading solid and liquid food samples in a hermetically sealed $1 \mathrm{ml}$ cavity to evaluate the heat resistance of bacterial spores when heated at temperatures above $100{ }^{\circ} \mathrm{C}$. Design of the test cell was governed by minimum come-up time. A finite element model based on the commercial software 'FEMLAB' was used to simulate transient heat transfer and finalize the test cell dimensions. Performance of the new test cell was evaluated against capillary and aluminum thermal death time tube methods in characterizing the heat resistance of Clostridium sporogenes PA 3679 spores in a phosphate buffer and mashed potato at $121^{\circ} \mathrm{C} . \mathrm{D}_{121}$ values of PA 3679 spores in both the phosphate buffer and mashed potato using the new test cells were not significantly different $(\mathrm{P}>0.05)$ from those by the capillary tube method. The results indicated that the new test cell is appropriate for studying the inactivation kinetics of bacterial spores in microbial validation of conventional and novel thermal processes for low acid shelf-stable foods.
\end{abstract}

Keywords: heat resistance, inactivation kinetics, thermal-death-time, heat transfer, finite element, microbial validation, thermal processing, low acid foods

\section{Introduction}

Ability to develop a new thermal treatment that produces safe foods depends upon both understanding the amount of heat delivered to every portion of a food product and knowledge of the thermal death kinetics of the target microorganisms. Microbial inactivation kinetic studies can help determine the heat resistances of food pathogens or acquire relevant thermal kinetics data for surrogates used to validate novel or conventional thermal processes. The heat resistance of a particular microorganism is needed to select process parameters such as temperature and time for inactivation of the target pathogen.

Heat resistance of bacteria is affected by various factors such as growth temperature, stage of growth, bacterial strains, composition, and the $\mathrm{pH}$ of the heating medium (Cameron, Leonard \& Barrett, 1980; Tomlins \& Ordal, 1976). The heat resistance of bacteria can be determined through thermal death time (TDT) tests. The instrumentation and equipment used for TDT tests include TDT retorts, tubes, cans; threeneck flask, sealed plastic pouches, and/or capillary tubes. The equipment used depends on the type of product being tested (i.e., low acid, acidified, thick puree, solid or liquid) and thus choosing an appropriate test method is critical to accurate determination of a bacteria's heat resistance.

Numerous studies have reported in the past for thermal death determination in real food systems. These include capillary tubes for liquid or semi-solid foods (Donnelly, Briggs \& Donnelly, 1987; Pandit, Tang, Mikhaylenko \& Liu, 2006; Wandling, Sheldon \& Foegeding, 1999), large glass tubes (10 $\mathrm{mm} \times 100 \mathrm{~mm}$ ) for solid foods (Carlier, Augstin \& Ropier, 1996; Donnelly et al., 1987), three-neck flask for beer pasteurization (Reveron, Barreiro \& Sandoval, 2005), sealed plastic pouches for meat products and vegetable soup (Abdul 
Ghani, Farid \& Chen, 2002; Farber \& Brown, 1990; Mazzotta, 2001a, 2001b), stomacher bags for ground beef (Juneja, Marks \& Mohr, 2003), aluminum tubes for salmon caviar (AlHoly, Quinde, Guan, Tang \& Rasco, 2004), aluminum tubes used with miniature retort system for tomato juice (Odlaug \& Pflug, 1977), thermal-death-time (TDT) cans, and thermoresistometers for pea puree (Cameron et al., 1980). Some of these methods are only suitable for determining the heat resistance of microorganisms at pasteurization temperatures $(<$ $100{ }^{\circ} \mathrm{C}$ ), so these will not work for spores at sterilization temperatures beyond $100{ }^{\circ} \mathrm{C}$ (Farber \& Brown, 1990).

Capillary tubes are considered the best method for characterizing heat-resistant bacterial spores in low acid liquid foods $>100{ }^{\circ} \mathrm{C}$, but they are not suitable for solid foods due to the difficulty of fitting samples in narrow tubes. TDT cans specifically designed for semi-solid and solid foods require a long incubation time (2-3 months) to obtain thermal inactivation results (Brown, 1992; Guan et al., 2003; Townsend, Somers, Lamb \& Olson, 1956). Thermoresistometers are specialized and expensive, hence available in only a few laboratories worldwide. Recently, Luechapattanaporn, Wang, Wang, Tang \& Hallberg (2004) described a novel aluminum tube for evaluating the heat resistance of bacterial spores in semi-solid and solid foods at sterilization temperatures. A major drawback of this aluminum tube was a long CUT of about $2.5 \mathrm{~min}$, which may have compromised the accuracy of the test results.

Current commercial thermal processes are based on the assumption of first-order microbial inactivation kinetics information (Holdsworth, 1997; Jay, 1996; Stumbo, 1973; Teixeira, 1992), which leads to logarithmic log-linear survivor curves. Many researchers, however, have observed nonlog-linear behaviors characterized by a broad shoulder during initial phase of heat treatment (Hills \& Mackey, 1995; Linton, Carter, Pierson \& Hackney, 1995). Deriving D-values from the linear portion of the survivor curves on a semilog plot will remedy this, but could lead to underestimation of the time and temperature needed to achieve a desired level of bacterial inactivation (Juneja \& Eblen, 2000). Chung, Wang \& Tang (2007) studied the effects of test tube sizes on heat transfer during the treatment of Escherichia coli in semisolid foods (i.e., mashed potato). The authors found that E. coli follows non-log-linear kinetics in large tubes, which they attributed to a relatively long come-up time (CUT, the time needed for the sample core temperature to reach $0.5^{\circ} \mathrm{C}$ less than the target process temperature) because of slow heat transfer at the center of the sample. The long thermal exposure could have induced heat shock proteins in the tested bacteria, leading to increased heat resistance. Stephens, Cole \& Jones (1994) showed that in Listeria monocytogenes, maximum thermotolerance induction occurred at heating rates $\leq$ $0.7^{\circ} \mathrm{C} / \mathrm{min}$. These studies lead to the conclusion that rapid heating processes minimize the chances of heat shock proteins being induced in microorganisms.

It is often desirable to determine the heat resistance of bacteria under isothermal conditions achieved through fast heat transfer in the test apparatus to reduce the influence of heat transfer. Although, the heat resistance of microorganisms in a phosphate buffer can be studied under close to isothermal conditions using capillary tubes as references for their intrinsic heat resistance characteristics in real food systems (Cameron et al., 1980; Guan et al. 2003; Nordsiden, Thompson, Wolf \& Zottola, 1978; Sorqvist, 1989), such information cannot be applied to food substrates because components such as fat, salt, water, $\mathrm{pH}$ level, or other conditions contribute to pathogen death or survival (Alderton, Ito \& Chen, 1976; Franz \& von Holy, 1996; Juneja \& Eblen, 2000).

The objectives of this study were to design simple-to-use test cells with short CUT for characterizing the heat resistance of bacterial spores in low acids foods at temperatures beyond $100{ }^{\circ} \mathrm{C}$, and to evaluate their use in determining the heat resistance of C. sporogenes (PA 3679) in selected food systems. C. sporogenes spores (PA 3679) were chosen because their thermal response characteristics are similar to those of C. botulinum, which is the most heat resistant and harmful microorganism known to human beings (Lund, 1975).

\section{Materials and Methods}

\subsection{Test cell design and development}

\subsubsection{Design criteria}

All-purpose test cell was needed because presently available test cells suffer from one or another limitations, as explained in the previous section. To overcome such limitations, the design of such test cell was guided by the following criteria:

1) sample holding capacity of at least $1 \mathrm{ml}$ for ease in preparation and post-treatment analysis of samples,

2) short CUT to provide practically isothermal conditions to the spores in food samples during heat treatment,

3) hermetical seal to allow sample heating above the water boiling point in oil baths, and

4) ease in loading and unloading liquid and solid samples.

In order to meet criteria 1 and 2, a computer simulation model based on the finite element method (FEM) was developed to aid in determining the test cell dimensions. General purpose Aluminum alloy 6061 was selected as a construction material for the test cells because of its high thermal conductivity, good corrosion resistance and machinability (Incropera \& Dewitt, 1996). Theoretically, test cell walls should be as thin as possible to offer minimal thermal resistance during heat transfer, yet provide adequate strength and integrity during machining of the test cells and handling of samples before and after thermal kinetics tests. The test cells also needed to provide adequate rigidity to prevent bulging caused by 
internal pressure generation when a moist sample is heated at temperatures beyond $100{ }^{\circ} \mathrm{C}$. The above reasons, we decided to design the cell walls at least $2 \mathrm{~mm}$ thick. When considering constraints in optimization of the cavity height, it was important to select a minimum distance between the thermocouple sensor tip distance and the cell wall to reduce errors for measuring sample center temperature. To minimize the thermal conduction effect though the sensor metallic sheath, the sensor tip was more than four times the sensor diameter away from the cell wall (Dour, Dargusch \& Davidson, 2006). For ease in loading and unloading, the test cells were made in two parts that could be quickly (in a minute time) screwed together by hand.

\subsubsection{Heat transfer modeling}

Modeling of heat transfer in the test cell requires a set of governing equations. Heat transfer in solid (aluminum alloy) and semi-solid (mashed potato) foods is mainly governed by conduction, which is mathematically expressed as:

$$
\frac{1}{\text { á }} \frac{\partial T}{\partial t}=-k \nabla^{2} T
$$

where $\mathrm{T}$ is temperature $\left({ }^{\circ} \mathrm{C}\right), \alpha$ is thermal diffusivity $\left(\mathrm{m}^{-2} \mathrm{~s}^{-1}\right)$, $\mathrm{t}$ is time (s) and $\mathrm{k}$ is the thermal conductivity $\left(\mathrm{W} \mathrm{m}^{-1} \mathrm{~K}^{-1}\right), \nabla$ is the delta operator.

For the test cell immersed in a well-stirred oil bath, convective heat transfer occurs at the interface of the test cell's and hot oil:

$$
h\left(T-T_{\infty}\right)=-k \frac{\partial T}{\partial t}
$$

where $\mathrm{T}_{\infty}$ is the temperature of the heating fluid $\left({ }^{\circ} \mathrm{C}\right)$ and $\mathrm{h}$ is the heat transfer coefficient $\left(\mathrm{Wm}^{-2} \mathrm{~K}^{-1}\right)$ at the oil and test cell interface. The thermal properties of the mashed potato and aluminum alloy used in the computer simulation are listed in Table 1 . The value of $h$ depends on the thermo-physical properties of the heating medium and geometry of the cell (Miller, Singh \& Farkas, 1994). In general, the value of $h$ is determined by comparing experimental and simulation results. Performing simulation with various $h$ values and comparing with experimental heating patterns it was decided to use 2500 $\mathrm{W} \mathrm{m} \mathrm{m}^{-2} \mathrm{~K}^{-1}$ in the simulation.

Table 1.Thermal properties of mashed potato and aluminum used for heating profile simulation

\begin{tabular}{lcc}
\hline Properties & Aluminum $(6061)^{\mathrm{a}}$ & Mashed potato $^{\mathrm{b}}$ \\
\hline Density, $\rho\left(\mathrm{kg} \mathrm{m}^{-3}\right)$ & 2702 & 1040 \\
Specific heat, ${ }^{\circ} \mathrm{C}\left(\mathrm{J} \mathrm{kg}^{-1} \mathrm{~K}^{-1}\right)$ & 903 & 3730 \\
Thermal conductivity, $\mathrm{k}\left(\mathrm{W} \mathrm{m}^{-1} \mathrm{~K}^{-1}\right)$ & 180 & 0.52 \\
\hline
\end{tabular}

a. ASM International, 1990

b. Fasina, Farkas \& Fleming, 2003
FEMLAB 3.3 (COMSOL Multiphysics, Burlington, MA, USA), a commercial finite element software, was used to numerically solve the Fourier equation (Eq. 1). Based on the criteria of a minimum $1 \mathrm{ml}$ sample size, various aspect ratios ranging from 1.5 to 6.5 for a $1 \mathrm{ml}$ cavity in the circular disk were simulated. The outer dimensions of the test cells were varied to provide a $2 \mathrm{~mm}$ wall thickness in all aspect ratios, as shown in Fig. 1. Since the disk-shape test cells had axial symmetric geometry, heat transfer was modeled for a 2-D space.

\subsubsection{Modeling and fabrication of test cells}

Upon determining the optimum aspect ratio of the $1 \mathrm{ml}$ sample cavity based on the stated design criteria, a final test cell design was prepared considering ease in handling of the test cell. The outer base of the test cell was profiled as square to provide a hand grip (Fig. 2). The test cell design change necessitated to develop another simulation model to predict the transient temperature profile. The domain was discretized in 3-D space by generating unstructured mesh consisting of 41655 tetrahedral elements for one quadrant of the test cell as shown in Fig. 2B. The mesh sizes and times used in the calculation were selected after convergence and stability tests. Computer simulations were performed on a Dell 670 computer with two Dual-Core, $2.80 \mathrm{GHz}$ XEON processors and 12 GB RAM running Windows XP on a 64-bit operating system.

\subsubsection{Validation of the finite element model}

Numerous design options were considered with the FEM simulation to select the dimension of the test cell. A test cell prototype was fabricated and evaluated in oil baths at $121^{\circ} \mathrm{C}$, and validated by comparing simulated temperature profiles with measured temperature profiles at the center of mashed potato sample heated in the test cell. Mashed potato sample filled test cells were immersed in $0{ }^{\circ} \mathrm{C}$ ice water for $30 \mathrm{~min}$ to achieve an equilibrium temperature before immersion in a $121{ }^{\circ} \mathrm{C}$ ethylene-glycol bath (Circulator HAAKE DC 30/ DL30, Thermo Electron, Germany). The core temperature of the mashed potato sample was measured using a thin pre-calibrated Type-T thermocouple (THQSS-020U-6, Dia $0.5 \mathrm{~mm}$, Omega Engineering Inc., Stanford, CT) and recorded with a data logger (DL2e, Delta-T Devices Ltd., Cambridge, UK) at a time interval of $5 \mathrm{~s}$.
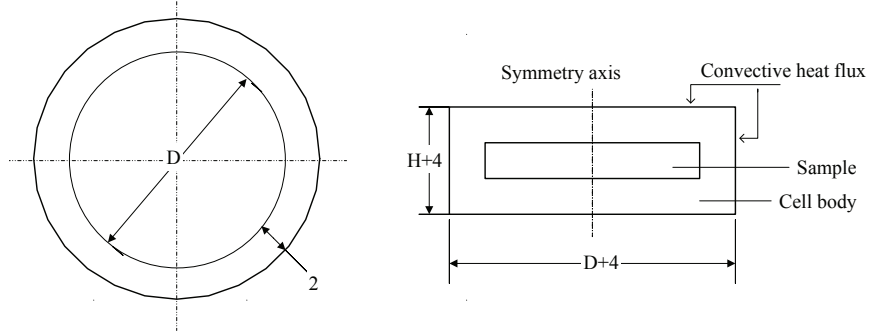

Fig. 1. Schematic representation of a disk-shaped test cell $(\mathrm{H}=$ height, $\mathrm{D}=$ diameter in $\mathrm{mm}$ ). 


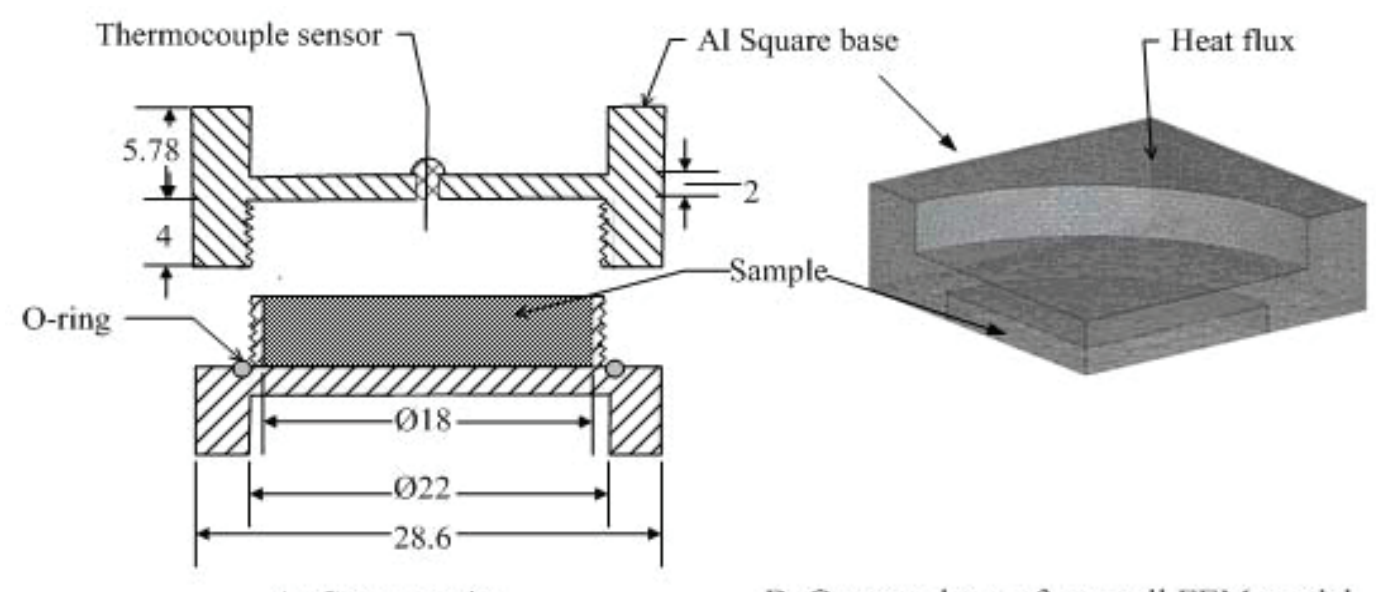

A. Cross section

B. One quadrant of test cell FEM model

Fig. 2. Schematic representation of a test cell with a $1 \mathrm{ml}$ disk cavity (A) of $18 \mathrm{~mm}$ diameter and $4 \mathrm{~mm}$ height, and finite element mesh on the top half of one quadrant (B)

\subsection{Performance evaluation of the designed test cell}

Evaluation of the new test cells' performance in characterizing the heat resistance of PA 3679 spores was made at 121 ${ }^{\circ} \mathrm{C}$, which is commonly used as a reference temperature in thermal process calculations (Teixeira, 1992; Toledo, 1991).

\subsubsection{Culture suspension}

C. sporogenes PA 3679 (SN 308) spores were procured from the Technical Service Center of the National Food Processors Association (NFPA, Dublin, CA, USA) for performance evaluation of the designed test cells. Upon receiving the PA 3679 spores, samples were inspected using a microscope. The spore suspension was heated at $90{ }^{\circ} \mathrm{C}$ for $10 \mathrm{~min}$ to enumerate and eliminate any possibility of vegetative cell survivors.

\subsubsection{Characterization of PA 3679 spores}

The thermal death behavior of the PA 3679 spores in a liquid phosphate buffer was characterized with the standard capillary tube method at four temperatures: 113, 118, 121, and $123{ }^{\circ} \mathrm{C}$. Glass capillary tubes (I.D. of $1 \mathrm{~mm}$ and O.D. of 3 mm, Rupe Zellner Science Kit Inc., Tonawanda, NY, USA) were autoclave-sterilized before being injected with $25 \mu \mathrm{l}$ of $\mathrm{M} / 15$ phosphate buffer solution ( $\mathrm{pH}$ 7.0) inoculated with C. sporogenes spores at $\sim 10^{6} \mathrm{CFU} / \mathrm{ml}$. The open ends of the tubes were heat-sealed at about $30 \mathrm{~mm}$ from the samples and submerged in an oil bath maintained at the preset temperatures listed above. Sets of tubes were removed every $30 \mathrm{~s}$ and cooled immediately in ice water. The tubes were washed in $70 \%$ ethyl alcohol prior to cutting both ends of the capillary tubes, with the sample material flushed from the tube using $3 \mathrm{ml}$ of $0.1 \%$ peptone water. Heat-treated samples were serially diluted in $0.1 \%$ peptone water. For control, sets of tubes containing unheated samples were handled similarly. Ten-fold serial dilutions were made in $0.1 \%$ peptone water and $1 \mathrm{ml}$ dilutions were pour-plated into TPGY (Trypton Pepton Glucose Yeast Extract) agar in duplicate (Whitmer \& Johnson, 1988). The plates were incubated at $32{ }^{\circ} \mathrm{C}$ for $48 \mathrm{~h}$ in an anaerobic chamber (Coy Laboratory Products Inc., Grass Lake, MI, USA). Each treatment was repeated twice. As each replicates was performed in duplicate, an average CFU/g of four platings of each sampling point (holding times) were used to estimate lethality kinetics (Juneja \& Eblen, 2000). The mean values of viable colony counts for each heating time were converted to log numbers and plotted vs. time in minutes. Dvalues were obtained by taking the negative reciprocal of the slope from the linear portion of the curves at $121^{\circ} \mathrm{C}$, and zvalues were obtained by plotting log D-values vs. the corresponding heating temperatures (Cameron et al., 1980).

\subsubsection{Comparison among capillary tube, TDT tube and de- signed test cell methods}

To study the effect of media on thermal resistance, an M/15 phosphate buffer and mashed potato were selected. Mashed potato was chosen because of its high viscosity, same mode of heat transfer (only conductive heat) in containers as that of other semi-solid and solid foods, as well as ease of use. Capillary tubes (I.D. of $1 \mathrm{~mm}$ and O.D. of $3 \mathrm{~mm}$ ) and aluminum TDT tubes were used as reference methods. Previously developed in our laboratory, the TDT tubes consisted of an aluminum tube with a $15 \mathrm{~mm}$ inner diameter and a solid aluminum bar with an $11 \mathrm{~mm}$ diameter (to speed the transfer of thermal energy from the screwed-on cap to the interior of the sample). The $2 \mathrm{~mm}$ cylindrical gap between the tube's inner wall and solid bar provided a holding capacity of up to $3 \mathrm{ml}$. The sample CUT was about $2.5 \mathrm{~min}$ when heated in an oil bath at 121 ${ }^{\circ} \mathrm{C}$. Detailed information on the design of this aluminum TDT tube can be found in Luechapattanaporn et al. (2004). 
For the capillary tube method, a $25 \mu \mathrm{l}$ phosphate buffer solution ( $\mathrm{pH} 7.0)$ or mashed potato $(0.25 \mathrm{~g} \pm 0.05)$ inoculated with C. sporogenes spores at $\sim 10^{6} \mathrm{CFU} / \mathrm{ml}$ was carefully injected into the tubes, as described earlier. Mashed potato at $15.38 \%$ wb was prepared by mixing potato flakes (Washington Potato Co., Warden, WA, USA) with distilled water. A sterilized syringe (18-gauge, 15.2 -cm long pipetting needle, Popper \& Sons, Inc., New Hyde Park, NJ, USA) was used to fill the mashed potato samples into the capillary tubes. Sets of prepared capillary tubes were heated in an oil bath at $121{ }^{\circ} \mathrm{C}$ from 0.5 to $4.5 \mathrm{~min}$, and removed at $30 \mathrm{~s}$ intervals. The selected exposure times were previously determined to reach a wide range of thermal kill. The post-heat treatments followed the same procedure. Following incubation, spores were enumerated and D-values determined.

For the new test cells and TDT tube methods, $1 \mathrm{ml}$ of phosphate buffer or $1 \mathrm{~g}$ of mashed potato inoculated with PA 3679 spores was placed inside sterile test cells and TDT tubes. The samples were kept on ice prior to heat treatment. The sealed test cells and TDT tubes were submerged for up to $4.5 \mathrm{~min}$ in an oil bath maintained at $121^{\circ} \mathrm{C}$, and removed at predetermined time (30 s) intervals. Heat-treated samples were serially diluted in $0.1 \%$ peptone water. The post-heat treatments in both the test units followed the same procedure as in the capillary tube method. As this study was meant for comparison purposes, the experiment was replicated twice only.

\subsection{Statistical analysis}

Determined D-values (from 3 different methods with two independent replicate experiments performed in duplicate) were subjected to an analysis of variance for determining significant differences $(\mathrm{P}<0.05)$ using PROC GLM procedure in SAS software (SAS Institute, Cary, NC, USA).

\section{Results and discussion}

\subsection{Test cell design}

The test cell design was guided by the shortest CUT in the geometric center of the samples. For the $1 \mathrm{ml}$ cavity, various aspect ratios (diameter/height) ranging from 2 to 6 were simulated and presented in Fig. 3. A decrease in sample thickness (increasing aspect ratio) reduced the CUT. The test cell walls did not offer much resistance to heat transfer in the sample, as the thermal conductivity of the aluminum alloy $\left(180 \mathrm{~W} \mathrm{~m}^{-1} \mathrm{~K}^{-}\right.$ $\left.{ }^{1}\right)$ was very high in comparison to that of the mashed potato $\left(0.52 \mathrm{~W} \mathrm{~m}^{-1} \mathrm{~K}^{-1}\right)$ sample. Sample thickness was thus identified as a critical parameter for reducing the CUT. However, to take care of the thermal conduction effect of the $0.5 \mathrm{~mm}$ diameter thermocouple, the sample thickness could not be less than $4 \mathrm{~mm}$ (Dour et al., 2006). An aspect ratio 4:5 fulfilled the minimum sample thickness requirement, so a cavity dimension with an $18 \mathrm{~mm}$ diameter and $4 \mathrm{~mm}$ height was finalized for the fabrication of the test cell. To meet the design

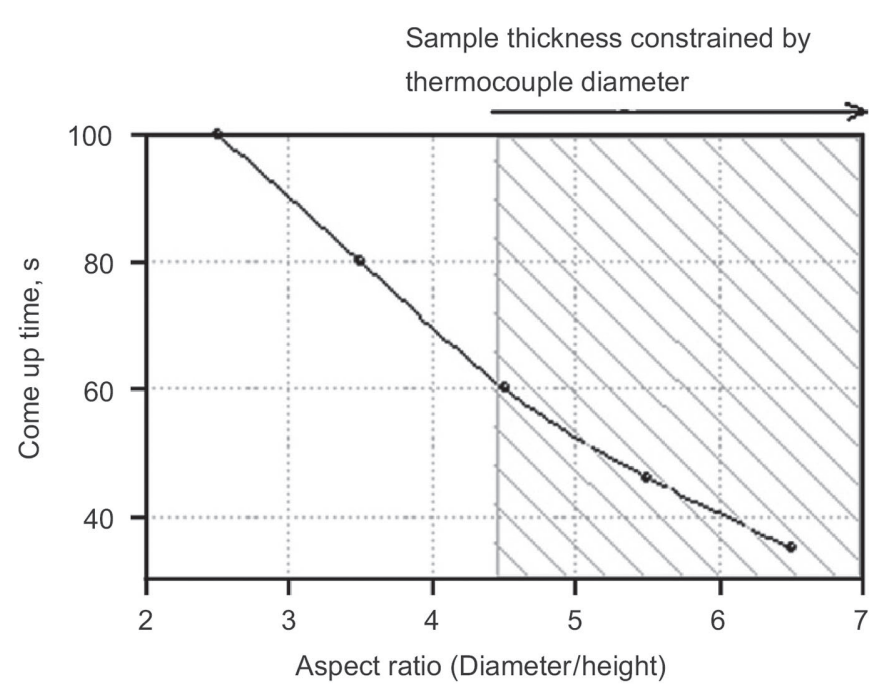

Fig. 3. Simulated effect of the aspect ratio (diameter/height of the sample cavity) on come-up time for the $1 \mathrm{ml}$ disk cavity of a test cell with a $2 \mathrm{~mm}$ wall thickness.

criteria of ease in sample handling, the test cell needed to be made from two pieces. However, screwing together two pieces with a small thickness and diameter by hand was predicted to be a problem, so the pieces were fabricated with an extended height $(3.78 \mathrm{~mm})$, as shown in Fig. 2. A screwed-on top piece with a rubber o-ring provided a hermetic seal (Fig. 2). To add more ease in handling, the test cells were shaped into squares $(28.6 \times 28.8 \times 7.8 \mathrm{~mm})$. The square pieces allowed easy closing and opening of the lid with a hand twist, and the alignment of the two square pieces served as an approximate indication of the appropriate tightness of the seal. A pre-calibrated thin-type T thermocouple was inserted through a rubber glance in the top cap to measure sample core temperature.

\subsection{Come-up-time of the designed test cell}

Performance of the test cell fabricated as per the specifications shown in Fig. 2 was evaluated experimentally as well as using the simulation model. Fig. 4 shows a measured and predicted temperature-time history of the mashed potato sample, whereas Fig. 5 illustrates simulated temperature distributions in a mashed potato sample and test cell after 20,40, 60, and $80 \mathrm{~s}$ of heating in a $121{ }^{\circ} \mathrm{C}$ oil bath. The results indicate that the temperature at the center of the test cell reached within 0.5 ${ }^{\circ} \mathrm{C}$ of $121{ }^{\circ} \mathrm{C}$ after $60 \mathrm{~s}$ of heating and within $0.2{ }^{\circ} \mathrm{C}$ of $121^{\circ} \mathrm{C}$ after $80 \mathrm{~s}$ of heating. Experimentally measured CUT for the mashed potato in the test cell was $65 \mathrm{~s}$, which was approximately half of the CUT for the aluminum TDT tubes (Luechapattanaporn et al., 2004). Although the test cell CUT time was still larger than the typical D-value of the microorganisms, but for given sample volume of the solids, the CUT was reasonably short. 


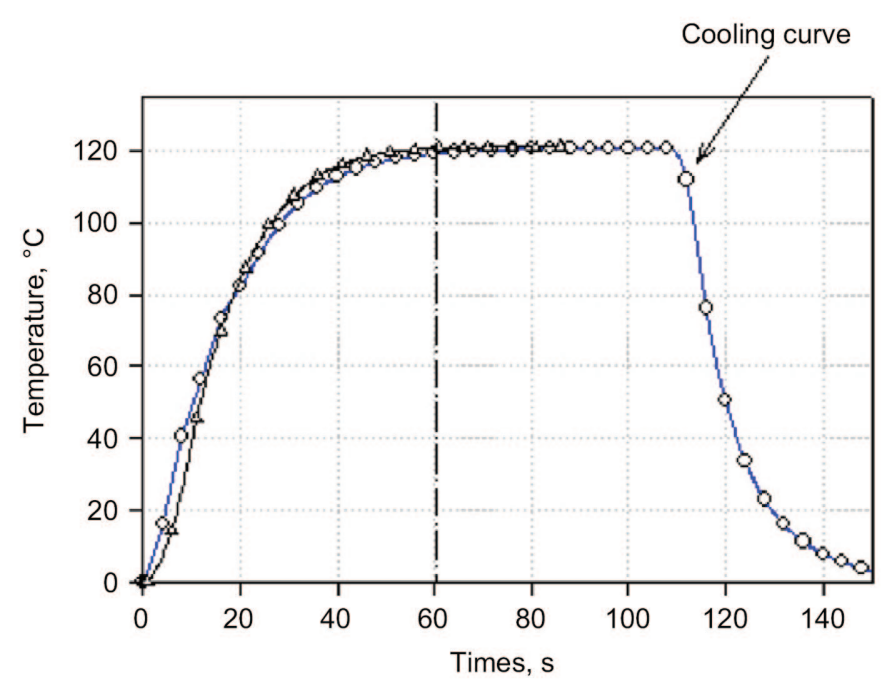

Fig. 4. Simulated $(\Delta)$ and experimental (o) temperature-time history at the center of a mashed potato sample sealed in a test cell, which was immersed in a $121^{\circ} \mathrm{C}$ oil bath.
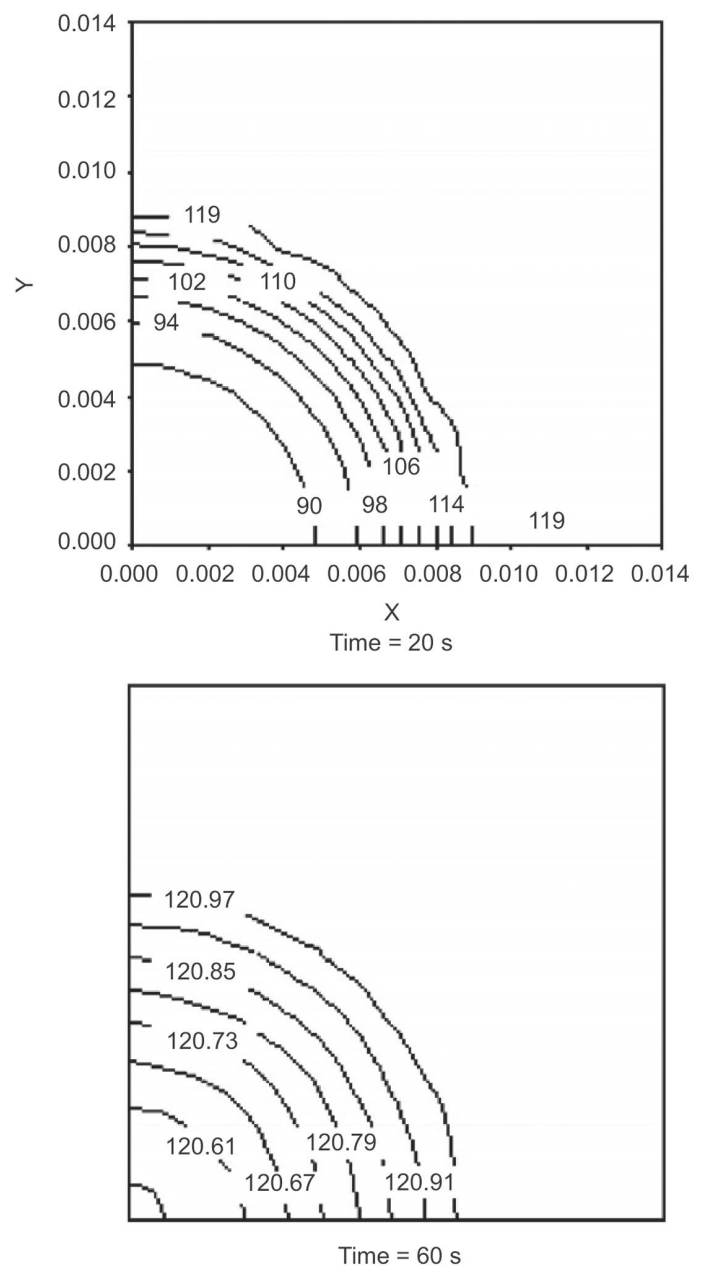

\subsection{Heat-resistant characteristics of the PA 3679 spores}

C. sporogenes is closely related to proteolytic strains of Clostridium botulinum but produces spores that are 3 to 5 times more heat-resistant (Brown, 1992). Fig. 6 shows the survival curves of C. sporogenes PA 3679 spores in a phosphate buffer $(\mathrm{pH} 7.0)$ at four temperatures determined with the capillary tube method. The $\mathrm{D}$-value at $121^{\circ} \mathrm{C}\left(\mathrm{D}_{121}\right)$ of PA 3679 spores in a phosphate buffer was $0.88 \pm 0.07 \mathrm{~min}$. Linear regression between $\log \mathrm{D}$ and temperatures $\left(\mathrm{R}^{2} \geq 0.9939\right)$ yielded $10.04 \pm 0.28{ }^{\circ} \mathrm{C}$ z-values (Fig. 6), which were close to that reported in the literature for C. sporogenes at $1.07 \mathrm{~min}$ and $9.33^{\circ} \mathrm{C}$, respectively, in a neutral phosphate buffer (Nordsiden et al., 1978). The PA 3679 spores used in our study were therefore considered appropriate for evaluating the performance of new test cell.

\subsection{Heat resistance of PA 3679 spores determined using de- signed test cells}

Fig. 7 shows PA 3679 spore inactivation kinetics at $121{ }^{\circ} \mathrm{C}$ in a phosphate buffer and mashed potato using the designed test cells, capillary and aluminum TDT tubes. With
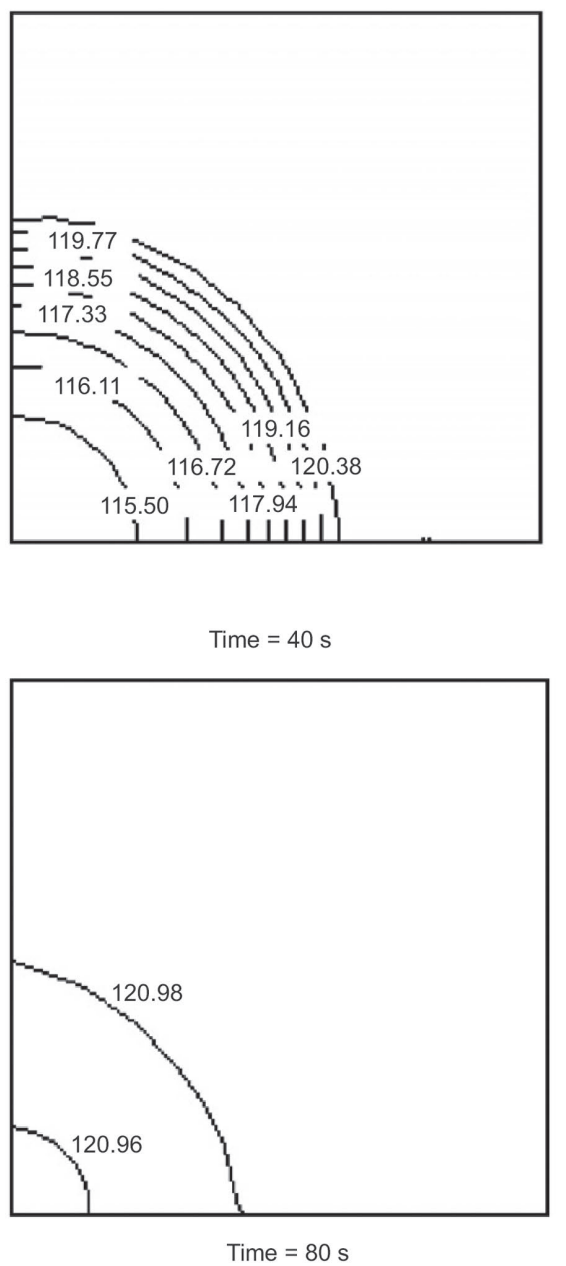

Fig. 5. Simulated temperature contour plot of a central cross-section of mashed potato sample and test cell after 20, 40, 60, and $80 \mathrm{~s}$ immersion in a $121^{\circ} \mathrm{C}$ oil bath. 
a

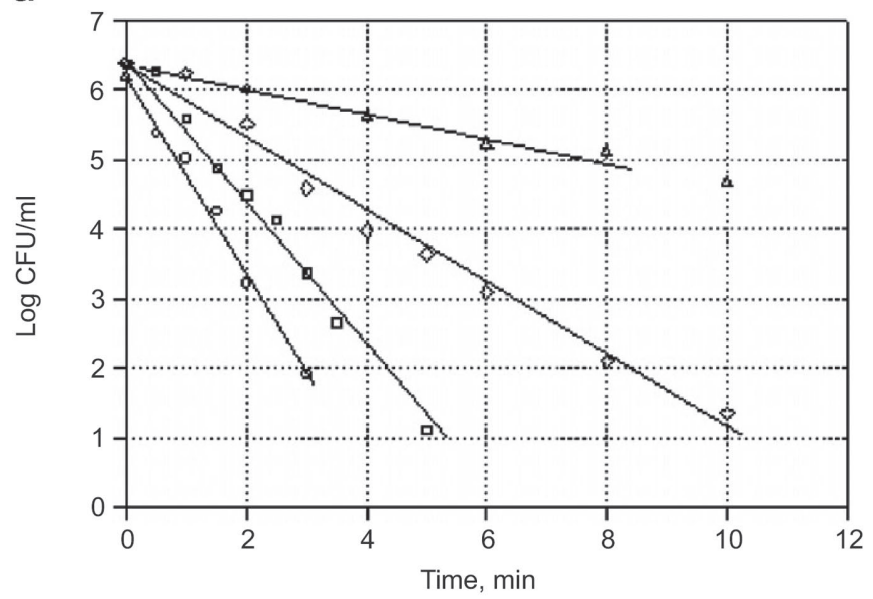

b

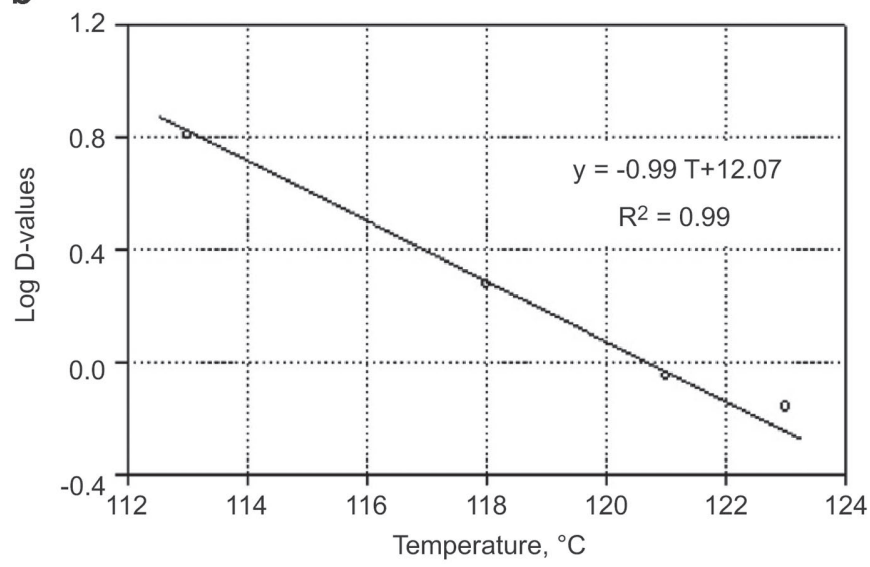

Fig. 6. Survival curves of Clostridium sporogenes PA 3679 spores in a phosphate buffer $(\mathrm{pH} 7.0)$ at $113(\Delta), 118(\diamond) 121(\square)$ and $123^{\circ} \mathrm{C}$ (O) temperature via the capillary tube method (a) and thermal death time curve of $\mathrm{C}$. sporogenes as a function of temperature (b).

the capillary tube method, PA 3679 spore survival curves were $\log$-linear in both the phosphate buffer $\left(\mathrm{R}^{2} \geq 0.979\right)$ and mashed potato samples $\left(\mathrm{R}^{2} \geq 0.993\right)$ after about $30 \mathrm{~s}$ of heating. Typical CUT for capillary tubes of the size used in this study was about $20 \mathrm{~s}$. The small shoulder in those curves reflects a short thermal lag. With the designed test cells, the shoulder in the survivor curves was extended to about 60 $\mathrm{s}$, while the shoulder for the curves determined with aluminum TDT tubes was about $120 \mathrm{~s}$. The PA 3679 spore survival curves associated with the designed test cells were very close to those with capillary tubes in both phosphate buffer and mashed potato (Fig. 7a and b).

$\mathrm{D}_{121}$ values for the PA 3679 spores were obtained from the log-linear portions of the survivor curves and are summarized in Table 2. The average $\mathrm{D}_{121}$ values obtained with the test cells were not significantly different from those by the capillary tube method $(\mathrm{P}>0.05)$ or TDT tubes for liquid samples (phosphate buffer). For semi-solid foods (mashed potato), the average $\mathrm{D}_{121}$ values obtained with the new test cells were also not significantly different from those by the capillary tube method $(\mathrm{P}>0.05)$, but significantly larger than that with TDT a

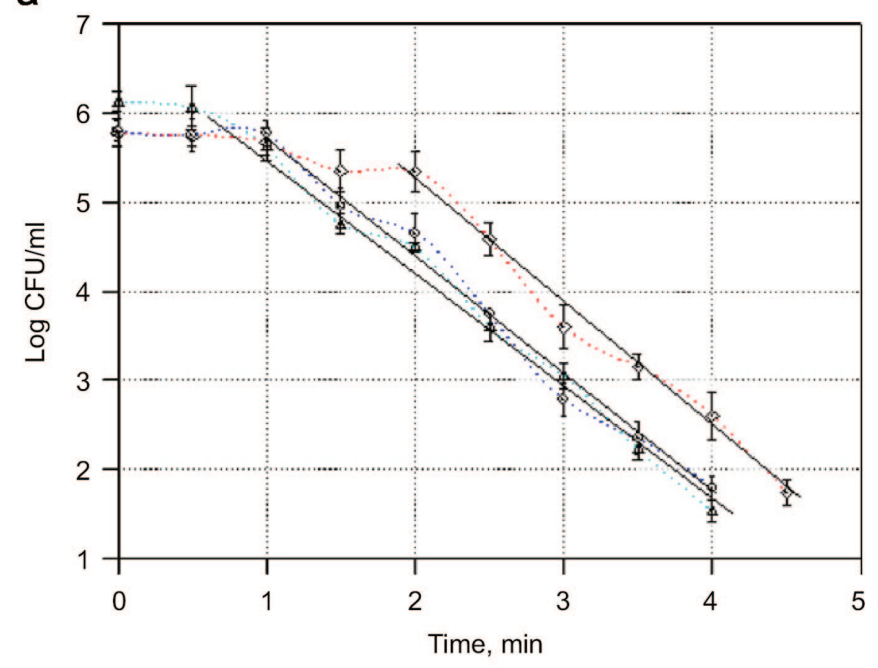

b

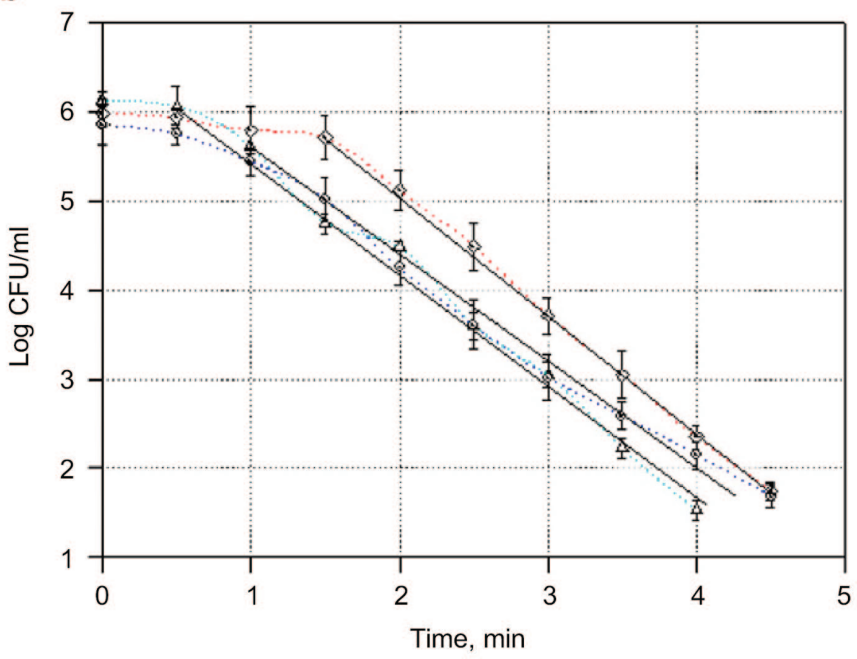

Fig. 7. Survival curves of Clostridium sporogenes PA 3679 spores in a phosphate buffer (a) and mashed potato (b) via capillary tube $(\Delta)$, TDT tube $(\diamond)$ and test cell $(O)$ methods.

Table 2. $\mathrm{D}_{121}$ values (mean \pm standard deviation) of Clostridium sporogenes PA 3679 in different media determined using different methods (two replicates)

\begin{tabular}{lllc}
\hline Food samples & Capillary tubes & Test cell & Aluminum TDT tube \\
\hline Phosphate buffer & $0.82 \pm 0.01 \mathrm{a}^{*}$ & $0.75 \pm 0.01 \mathrm{ab}$ & $0.72 \pm 0.04 \mathrm{~b}$ \\
Mashed potato & $0.98 \pm 0.01 \mathrm{a}$ & $0.92 \pm 0.06 \mathrm{a}$ & $0.72 \pm 0.08 \mathrm{~b}$ \\
\hline
\end{tabular}

* Different letters for D-values indicate that means are significant among three different methods $(\mathrm{P}<0.05)$

tubes $(\mathrm{P}<0.05)$. This suggests that the new test cells can accurately determine the heat resistance of PA 3679 in semi-solid and solid foods, while the TDT tubes underestimated the heat resistance of PA 3679 spores in those samples.

Different methods for testing the heat resistance of bacteria in foods have been studied by many researchers. For example, Cameron et al. (1980) compared the D-values of C. sporogenes spores in a phosphate buffer using the capillary tube method with the D-values in pea puree by the TDT can 
method. The authors reported nine times higher D-values and a slightly higher z-value in pea puree with TDT cans than the capillary tube method with a phosphate buffer at the same $\mathrm{pH}$. Al-Holy et al. (2004) reported the heat resistance of L. innocua in salmon caviar by aluminum TDT tubes and glass tubes. To our knowledge, no direct comparison of bacterial spore heat resistance by capillary tube methods with other test methods in food samples exists.

Our results indicate that the developed test cell can serve as a reliable experimental tool for studying the inactivation kinetics of bacterial spores in semi-solid and solid foods at temperatures beyond $100 \mathrm{C}$. By shortening the lag period during the CUT, the test cells were able to provide a uniform heating environment to C. sporogenes distributed in mashed potato sample. The unique feature of the test cell may help in precisely characterize the heat resistance of other bacterial species in semi-solid and solid foods to further develop sterilization and pasteurization processes. Accurate assessment of the heat resistance of additional targeted bacteria in thermal processing will help to provide better processing parameters for producing higher quality and safer food products.

Acknowledgment-We acknowledge financial support from the Washington State University Agriculture Research Center and USDA National Integrated Food Safety Initiative, Grant No. 2003-5111002093, titled "Safety of foods processed using four alternative processing technologies."

\section{References}

Abdul Ghani, A. G., Farid, M. M., \& Chen, X. D. (2002). Theoretical and experimental investigation of the thermal inactivation of Bacillus stearothermophilus in food pouches. Journal of Food Engineering, 51, 221-228.

Al-Holy, M., Quinde, Z., Guan, D., Tang, J., \& Rasco, B. (2004). Thermal inactivation of Listeria innocua in salmon (Oncorhynchus keta) caviar using conventional glass and novel aluminum thermal-death-time tubes. Journal of Food Protection, 67, 383-386.

Alderton, G., Ito, K. A., \& Chen, J. K. (1976). Chemical manipulation of the heat resistance of Clostridium botulinum spores. Applied and Environmental Microbiology, 31, 492-498.

ASM International (1990). ASM metals handbook, vol. 2: properties and selection: nonferrous alloys and special-purpose materials (10th ed.). Materials Park, OH: ASM International.

Brown, K. L. (1992). Heat resistance of bacterial spores. Ph.D. Thesis: University of Nottingham, UK.

Cameron, M. S., Leonard, S. J., \& Barrett, E. L. (1980). Effect of moderately acidic $\mathrm{pH}$ on heat resistance of Clostridium sporogenes in phosphate buffer and in buffered pea puree. Applied and Environmental Microbiology, 39, 943-949.

Carlier, V., Augstin, J. C., \& Ropier, J. (1996). Heat resistance of Listeria monocytogenes (Phagovar 2389/2425/3274/2671/108/340): D- and z-values in ham. Journal of Food Protection, 59, 588-591.
Chung, H. -J., Wang, S., \& Tang, J. (2007). Influence of heat transfer in tube methods on measured thermal inactivation parameters for Escherichia coli. Journal of Food Protection, 70, 851-859.

Donnelly, C. W., Briggs, E. H., \& Donnelly, L. S. (1987). Comparison of heat resistance of Listeria monocytogenes in milk as determined by two methods. Journal of Food Protection, 50, 14-17; 20.

Dour, G., Dargusch, M., \& Davidson, C. (2006). Recommendations and guidelines for the performance of accurate heat transfer measurements in rapid forming processes. International Journal of Heat and Mass Transfer, 49(11-12), 1773-1789.

Farber, J. M., \& Brown, B. E. (1990). Effect of prior heat shock on heat resistance of Listeria monocytogenes in meat. Applied and Environmental Microbiology, 56, 1584-1587.

Fasina, O. O., Farkas, B. E., \& Fleming, H. P. (2003). Thermal and dielectric properties of sweetpotato puree. International Journal of Food Properties, 6(3), 461-472.

Franz, C. M. A. P., \& von Holy, A. (1996). Thermotolerance of meat spoilage lactic acid bacteria and their inactivation in vacuum-packaged Vienna sausages. International Journal of Food Microbiology, 29, 59-73.

Guan, D., Gray, P., Kang, D. H., Tang, J., Shaffer, B., Ito, K., Younce, F., \& Yang, T. C. S. (2003). Microbiological validation of microwave-circulated water combination heating technology by inoculated pack studies. Journal of Food Science, 68, 1428-1432.

Hills, B. P., \& Mackey, B. M. (1995). Multi-compartment kinetic models for injury; resuscitation induced log and growth in bacterial cell populations. Food Microbiology, 12, 333-346.

Holdsworth, S. D. (1997). Thermal processing of packaged foods. London: Blackie Academic Professional.

Incropera, F. P., \& Dewitt, D. P. (1996). Introduction to heat transfer. New York: John Wiley \& Sons.

Jay, J. M. (1996). Modern food microbiology. New York: Chapman \& Hall.

Juneja, V. K., \& Eblen, B. S. (2000). Heat inactivation of Salmonella typhimurium DT104 in beef as affected by fat content. Letters in Applied Microbiology, 30, 461-467.

Juneja, V. K., Marks, H. M., \& Mohr, T. (2003). Predictive thermal inactivation model for effects of temperature; sodium lactate; $\mathrm{NaCl}$; and sodium pyrophosphate on Salmonella serotypes in ground beef. Applied and Environmental Microbiology, 69, 5138-5156.

Linton, H., R., Carter, W. H., Pierson, M. D., \& Hackney, C. R. (1995). Use of a modified Gompertz equation to model nonlinear survival curves for Listeria monocytogenes. Journal of Food Protection, 58, 946-951.

Luechapattanaporn, K., Wang, Y., Wang, J., Tang, J., \& Hallberg, L. M. (2004). Microbial safety in radio frequency processing of packaged foods. Journal of Food Science, 67(7), M201-206.

Lund, D. B. (1975). Heat processing. In M.Karel, O. Fennema \& D. Lund. Principles of food science (pp. 31-92). New York: Marcel Dekker. 
Mazzotta, A. S. (2001a). Heat resistance of Listeria monocytogenes in vegetables evaluation of blanching process. Journal of Food Protection, 64, 385-387.

Mazzotta, A. S. (2001b). Thermal inactivation of stationary phase and salt-adapted Listeria monocytogenes during postprocess pasteurization of surimi-based imitation crabmeat. Journal of Food Protection, 64, 483-485.

Miller, K. S., Singh, R. P., \& Farkas, B. E. (1994). Viscosity and heat transfer coefficients for canola, corn, palm and soybean oil. Journal of Food Processing and Preservation, 18, 461-472.

Nordsiden, K. L., Thompson, D. R., Wolf, I. D., \& Zottola, E. A. (1978). Home canning of food: effect of higher process temperature $(250 \mathrm{HF})$ on the safety of low-acid foods. Journal of Food Science, 43, 1734.

Odlaug, T. E., \& Pflug, I. J. (1977). Thermal destruction of Clostridium botulinum spores suspended in tomato juice in aluminum thermal death time tubes. Applied and Environmental Microbiology, 34, 23-29.

Pandit, R. B., Tang , J., Mikhaylenko, G., \& Liu, F. (2006). Kinetics of chemical marker M-2 formation in mashed potato-a tool to locate cold spots under microwave sterilization. Journal of Food Engineering, 76, 353-361.

Reveron, I. M., Barreiro, J. A., \& Sandoval, A. J. (2004). Thermal death characteristics of Lactobacillus paracasei and Aspergillus niger in Pilsen beer. Journal of Food Engineering, $66,239-243$.

Sorqvist, S. (1989). Heat resistance of Campylobacter and Yersinia strains by three methods. The Journal of Applied Bacteriology, 67, 543-549.
Stephens, P. J., Cole, M. B., \& Jones, M. V. (1994). Effect of heating rate on the thermal inactivation of Listeria monocytogenes. The Journal of Applied Bacteriology, 77, 702-708.

Stumbo, C. R. (1973). Thermobacteriology in food processing (2nd ed.). New York: Academic Press.

Teixeira, A. (1992). Thermal process calculations. In D. R. Heldman, \& D. B. Lund. Handbook of food engineering. New York: Marcel Dekker.

Toledo, R. T. (1991). Thermal process calculations. In R. T. Toledo. Fundamentals of food process engineering (pp. 315-397). New York: Chapman \& Hall.

Tomlins, R. I., \& Ordal, Z. J. (1976). Thermal injury and inactivation in vegetative bacteria. In: F. A.Skinner, \& W. B. Hugo. Inhibition and inactivation of vegetative microbes (pp. 153190). New York: Academic Press.

Townsend, C. T., Somers, I. I., Lamb, F. C., \& Olson, N. A. (1956). A laboratory manual for the canning industry (2nd ed.). Washington, DC: National Canners Association.

Wandling, L. R., Sheldon, B. W., \& Foegeding, P. M. (1999). Nisin in milk sensitizes Bacillus spores to heat and prevents recovery of survivors. Journal of Food Protection, 62, 492-498.

Whitmer, M. E., \& Johnson, E. A. (1988). Development of improved defined media for Clostridium botulinum serotypes A, B, and E. Applied and Environmental Microbiology, 54, 753-754. 